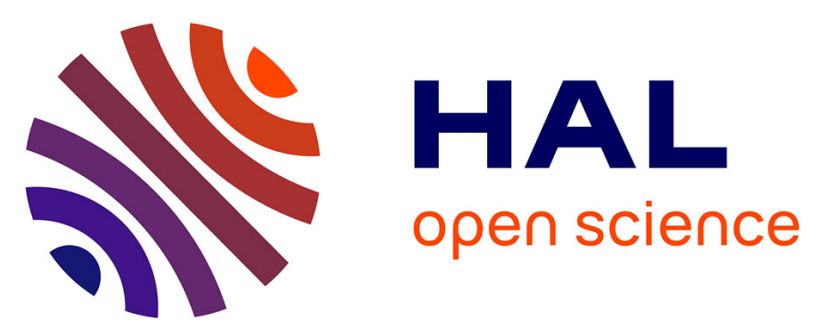

\title{
Calibration of stable isotope composition of Thoracosphaera heimii (dinoflagellate) calcite for reconstructing paleotemperatures in the intermediate photic zone
}

Fabrice Minoletti, Michaël Hermoso, Yaël Candelier, Ian Probert

\section{To cite this version:}

Fabrice Minoletti, Michaël Hermoso, Yaël Candelier, Ian Probert. Calibration of stable isotope composition of Thoracosphaera heimii (dinoflagellate) calcite for reconstructing paleotemperatures in the intermediate photic zone. Paleoceanography, 2014, 29 (12), pp.1111-1126 10.1002/2014PA002694 . hal-01103331

\section{HAL Id: hal-01103331 \\ https: / hal.sorbonne-universite.fr/hal-01103331}

Submitted on 14 Jan 2015

HAL is a multi-disciplinary open access archive for the deposit and dissemination of scientific research documents, whether they are published or not. The documents may come from teaching and research institutions in France or abroad, or from public or private research centers.
L'archive ouverte pluridisciplinaire HAL, est destinée au dépôt et à la diffusion de documents scientifiques de niveau recherche, publiés ou non, émanant des établissements d'enseignement et de recherche français ou étrangers, des laboratoires publics ou privés. 


\section{Paleoceanography}

\section{RESEARCH ARTICLE \\ 10.1002/2014PA002694 \\ Key Points: \\ - Thoracosphaera heimii precipitates calcite with near-equilibrium $\delta{ }^{18} \mathrm{O}$ values \\ - Very dilute batch cultures agree \\ Calibration of stable isotope composition of Thoracosphaera heimii (dinoflagellate) calcite for reconstructing paleotemperatures in the intermediate photic zone} with near-monospecific core top assemblages

- $\delta{ }^{18} \mathrm{O}$ of $T$. heimii allows reconstructing intermediate photic zone temperature

Correspondence to:

F. Minoletti,

fabrice.minoletti@upmc.fr

\section{Citation:}

Minoletti, F., M. Hermoso, Y. Candelier, and I. Probert (2014), Calibration of stable isotope composition of Thoracosphaera heimii (dinoflagellate) calcite for reconstructing paleotemperatures in the intermediate photic zone, Paleoceanography, 29, doi:10.1002/ 2014 PA002694.

Received 8 JUL 2014 Accepted 29 OCT 2014 Accepted article online 30 OCT 2014

\author{
Fabrice Minoletti ${ }^{1,2}$, Michaël Hermoso ${ }^{3}$, Yaël Candelier ${ }^{1,2}$, and lan Probert ${ }^{4,5}$ \\ ${ }^{1}$ UPMC Université Paris 06, Paris, France, ${ }^{2}$ CNRS, Paris, France, ${ }^{3}$ Department of Earth Sciences, University of Oxford, Oxford, \\ United Kingdom, ${ }^{4}$ UPMC, Roscoff, France, ${ }^{5}$ CNRS, Roscoff, France
}

\section{Introduction}

Generating reliable sea surface temperatures (SSTs) is a principle aim for paleoceanographers and is fundamental for successful modeling of climate sensitivity in the past, present, and future. This has motivated considerable effort in the development of paleotemperature proxies, yet uncertainties remain on the fidelity of SST estimates. Most of the studies aiming to derive paleotemperatures are based on planktic foraminifera oxygen isotope composition $\left(\delta^{18} \mathrm{O}\right)$ because their tests can be easily isolated from sediments by hand-picking.

Calcareous phytoplankton algae, such as coccolithophores and calcareous dinoflagellates, thrive in the photic zone, and hence, calcification takes place close to the interface between the atmosphere and the ocean. The geochemistry of their shells may hence represent a valuable addition to the paleoceanography toolbox to augment data from foraminifera enabling more precise reconstruction of the physico-chemistry of the photic zone. The increasing interest in phytoplankton geochemistry has been made possible by recent development and application of sedimentological techniques enabling the isolation and geochemical analysis of their micronsized calcified shells [Minoletti et al., 2001; Stoll and Ziveri, 2002; Minoletti et al., 2004; Minoletti et al., 2005; Stoll, 2005; Zonneveld et al., 2007; Hermoso et al., 2009; Minoletti et al., 2009; Bolton et al., 2012; Rousselle et al., 2013].

Calcareous dinoflagellates mainly thrive in warm, low-latitude waters often characterized by low nutrient levels [Zonneveld et al., 2000; Kohn and Zonneveld, 2010]. In situ measurements have shown that maximum abundance of living cells is found in the photic zone below the mixed layer although it has to be acknowledged that this observation comes from very dilute cell counts [Karwath et al., 2000; Vink et al., 2000; Wendler et al., 2002a, 2002b; Vink, 2004; Kohn and Zonneveld, 2010]. This putative deeper habitat with respect to that of the coccolithophores owes to their intolerance to high-energy water motion [Thomas and Gibson, 1990]. 


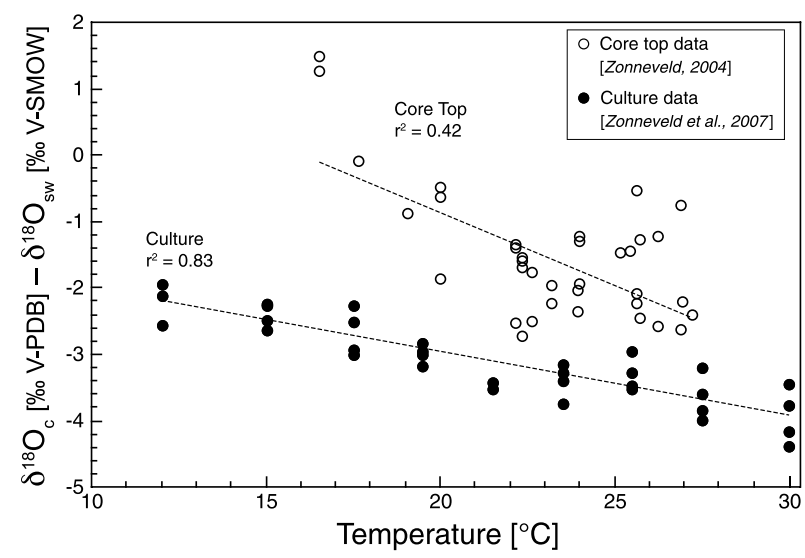

Figure 1. Previously reported magnitude of oxygen isotope fractionation estimated by the $\delta-\delta$ notation for $T$. heimii calcite from culture (black circles) and core tops (open circles). Data are from Zonneveld et al. [2007] and Zonneveld [2004], respectively. There is a good overall relationship between temperature and oxygen isotope composition of cultured calcispheres, with replicates comprised within a mean $1 \%$ o array for the same temperature. The relatively negative $\delta^{18} \mathrm{O}$ values indicate a vital effect toward isotopically light values. Hence, these data indicate that $T$. heimii calcite can be tentatively assigned to the "light group" (sensu Dudley et al. [1986]). Conversely, in the core top study, no correlation is found between temperature and $\delta^{18} \mathrm{O}$, with significantly more positive $\delta^{18} \mathrm{O}$ values with respect to the culture data.
Another contrasting feature with the coccolithophores is the mode of biomineralization of $T$. heimii dinoflagellates with a combined external and internal precipitation of calcite, as originally described based on morphological observations of living cells [Tangen et al., 1982]. This feature has been subsequently supported by geochemical evidence [Gussone et al., 2010; Van de Waal et al., 2013]. Morphological and molecular investigations indicate that $T$. heimii-like morphologies and genes are present since the Upper Cretaceous [Hildebrand-Habel et al., 1999; Gottschling et al., 2008]. This long lasting record indicates that monospecific $T$. heimii analyses may enable a long-term investigation of the thermal evolution of the intermediate photic zone.

To date, the comprehensive culture study of Zonneveld et al. [2007] is the only one that has measured ${ }^{18} \mathrm{O}$ fractionation (approximated from the difference between $\delta^{18} \mathrm{O}_{\mathrm{c}}$ and $\delta^{18} \mathrm{O}_{\text {medium }}$ ) in $T$. heimii calcite under a wide range of growth temperatures (Figure 1). The authors observed a strong linear correlation $\left(r^{2}=0.83\right)$ between temperature and oxygen isotope composition of $T$. heimii calcite. Compared to inorganic prediction [Kim and O'Neil, 1997], T. heimii calcite was measured with significantly negative $\delta^{18} \mathrm{O}_{c}$, with a mean offset of $-3 \%$. In sediments, despite the careful methodological approach presented by Zonneveld [2004], no convincing correlation could be found between temperature and $\delta^{18} \mathrm{O}$ of $T$. heimii in Atlantic Ocean core tops $\left(r^{2}=0.42\right)$ (Figure 1). Values of $\delta^{18} \mathrm{O}_{\mathrm{c}}$ obtained from separated fractions were also significantly higher ( 1.5\%o) than culture residues. Hence, the inconsistency between culture and core top data makes the achieved calibration hardly transferable to the geological record [Kohn and Zonneveld, 2010]. Recent reappraisals of the magnitude of the vital effect, i.e., the isotopic offset between biominerals and inorganic calcite precipitated from the same fluid, in "geologically relevant" coccoliths have highlighted the influence of the culture method on the isotopic composition of calcite (see review by Hermoso [2014]). Discrepancies in the magnitude of vital effects between studies are the likely consequence of culture artifacts-primarily due to a reservoir effect affecting the pool of dissolved inorganic carbon (DIC) [Hermoso et al., 2014]. Indeed, when cultured at very low cell density, coccolith calcite has been reported closer to equilibrium and matches the core top data [Candelier et al., 2013].

In this study, we attempt an integrated culture and core top calibration using state-of-the-art methodologies to calibrate stable isotope composition for T. heimii with a geological (Cenozoic) perspective. We have carried out very dilute batch cultures in the laboratory to minimize possible culture artifacts and applied a microseparation technique to produce near-monospecific (>90\%) T. heimii fractions that is based on a cascade of micro-filtering steps [Minoletti et al., 2009]. Beyond a simple empirical calibration and discussion of the discrepancies with previous studies, here we attempt a mechanistic understanding of the vital effect in T. heimii affecting the oxygen isotope composition, and we discuss the applicability of the paleotemperature proxy based on monospecific fractions of $T$. heimii. In addition to oxygen isotopes, we present carbon isotope data indicating that temperature might exert a second-order control on $\delta^{13} \mathrm{C}$ calcite in T. heimii.

\section{Material and Methods}

\subsection{Culture Setup}

Studies based on laboratory cultures of calcifying organisms have provided calibration equations that enable translation of $\delta^{18} \mathrm{O}_{c}$ into temperature estimates for a wide range of planktic calcifiers [Dudley et al., 1986; 
Bemis et al., 1998; Ziveri et al., 2003; Candelier et al., 2013]. There are many methodological issues, spanning from purely inorganic to physiological aspects that can contribute to altering the isotopic values in laboratory cultures [Hinga et al., 1994; Langer et al., 2006; Barry et al., 2010; Candelier et al., 2013; Hermoso et al., 2014]. This point is well illustrated by the fact that in several cases, significantly different isotopic compositions and fractionation factors have been documented in different studies on the same species (see synthesis in Stoll and Ziveri [2004] and Hermoso et al. [2014]). As most of these artifacts originate from a drift of the carbonate system ([DIC] and $\mathrm{pH}$ ) in the culture medium, it has been recommended to keep biomass low during batch culture experiments, implying harvesting the bioassay at very dilute cell concentration [Barry et al., 2010].

With these potential artifacts in mind, we conducted dilute batch cultures of a monoclonal strain of Thoracosphaera heimii (RCC 1511 from the Roscoff Culture Collection: http://www.roscoff-culture-collection. org) originated from Japanese coastal waters. This strain was grown at seven temperatures between 13 and $27^{\circ} \mathrm{C}$. The batch cultures were undertaken in $2.7 \mathrm{~L}$ Nalgene polycarbonate flasks, without a headspace. The culture medium consisted of aged English Channel seawater, with nutrient, trace metal, and chelator enrichments corresponding to K/6 [Keller et al., 1987] and vitamins to that of the $f / 2$ recipe [Guillard, 1975]. Prior to sterilization, media were bubbled with atmospheric air for $24 \mathrm{~h}$. $\mathrm{pH}$ was adjusted to 8.2 by addition of $0.2 \mathrm{M} \mathrm{NaOH}$, and sterilization of the culture medium was achieved by filtration through a $0.22 \mu \mathrm{m}$ pore size Stericup filter device. Cultures were illuminated by using daylight fluorescent bulbs at a light intensity of $\sim 150 \mu \mathrm{mol}$ photons $\mathrm{m}^{-2} \mathrm{~s}^{-1}$ with a 14/10 light/dark photoperiod.

Prior to the start of the experiment, cultures were gradually acclimated $\left(0.5^{\circ} \mathrm{C} /\right.$ day $)$ to the target temperature and maintained for at least 10 generations at the target temperature. The initial cell density of $T$. heimii in the experiments was $\sim 50$ cells per $\mathrm{mL}$. Aliquots of the culture medium were sampled at the beginning and end of the experiments, filtered through a $0.22 \mu \mathrm{m}$ disc-syringe filter and kept at $4^{\circ} \mathrm{C}$ for subsequent measurement of $\delta^{18} \mathrm{O}_{\mathrm{sw}}$ of the culture medium. Bubbling of the culture media at $15^{\circ} \mathrm{C}$ with ambient air was undertaken to ensure that the DIC level and $\delta^{13} \mathrm{C}$ of DIC were in equilibrium with the atmosphere [Zeebe et al., 1999]). By applying the same procedure, Hermoso et al. [2014] measured carbon isotope composition of the DIC in the culturing medium close to $0 \%$.

The culture flasks were gently shaken twice a day to allow redistribution of the cells in the flask. Cell counts were undertaken using a Sedgewick-Rafter cell containing a subsample of $1 \mathrm{~mL}$ of medium and observed under an inverted microscope. Cultures were harvested when cell density reached between 6000 and 15,000 cells per $\mathrm{mL}$. At this stage, population growth was still at the early stage of the exponential phase and therefore under nutrient- and DIC-replete conditions. For each temperature, cultures were implemented in duplicate. At $15^{\circ} \mathrm{C}$, two additional flasks were left grown until the population reached late exponential phase in order to assess the effect of the cell density and consequent chemical drift of medium composition on isotope composition in T. heimii calcite.

\subsection{Core Top Samples}

\subsubsection{Location of Samples Sites}

Core top samples were selected from two oceanographic settings. Seven sites were recovered from intermediate latitudes at $30^{\circ} \mathrm{S}$ in the Southern Atlantic and Indian oceans and between $20^{\circ} \mathrm{N}$ and $40^{\circ} \mathrm{N}$ in the Northern Atlantic and one from the Northern Somali Basin at $4^{\circ} \mathrm{N}$ (Table 1). Except for the Somali site, all sites are located within or at the edge of oceanic gyres. The sampling interval was always the topmost few centimeters of each core. The relatively recent age of sedimentary particles enables core top calibration with environmental parameters assumed to be close to present day conditions.

\subsubsection{Retrieving Environmental Parameters $\left(T, \delta^{18} O_{s w}\right)$ for the Calibration}

Calcification of T. heimii takes place in the intermediate photic zone, typically at or just below the base of the mixed layer [Karwath et al., 2000; Vink et al., 2000; Wendler et al., 2002a, 2002b; Vink, 2004; Kohn and Zonneveld, 2010]. To assess the environmental parameters of this water mass, we first evaluated the depth of the mixed layer, the base of which was defined using seawater potential density [Levitus and de Boyer Montégut, 1994; de Boyer Montégut, 2004]. Values of mean annual temperature and $\delta^{18} \mathrm{O}_{\mathrm{sw}}$ for the Intermediate Photic zone were then integrated over a $30 \mathrm{~m}$ thick water mass below the base of the mixed layer, on average between 50 and $80 \mathrm{~m}$ (Table 1). Temperature and $\delta^{18} \mathrm{O}_{\mathrm{sw}}$ were retrieved from the World Ocean Atlas 2009 [Locarnini et al., 2010] and from the global $1^{\circ} \times 1^{\circ}$ gridded compilation of LeGrande and Schmidt [2006]. Temperature values are comprised between 15 and $27^{\circ} \mathrm{C}$, which is a similar range to that of the culture experiments $\left(13-27^{\circ} \mathrm{C}\right.$ ). 


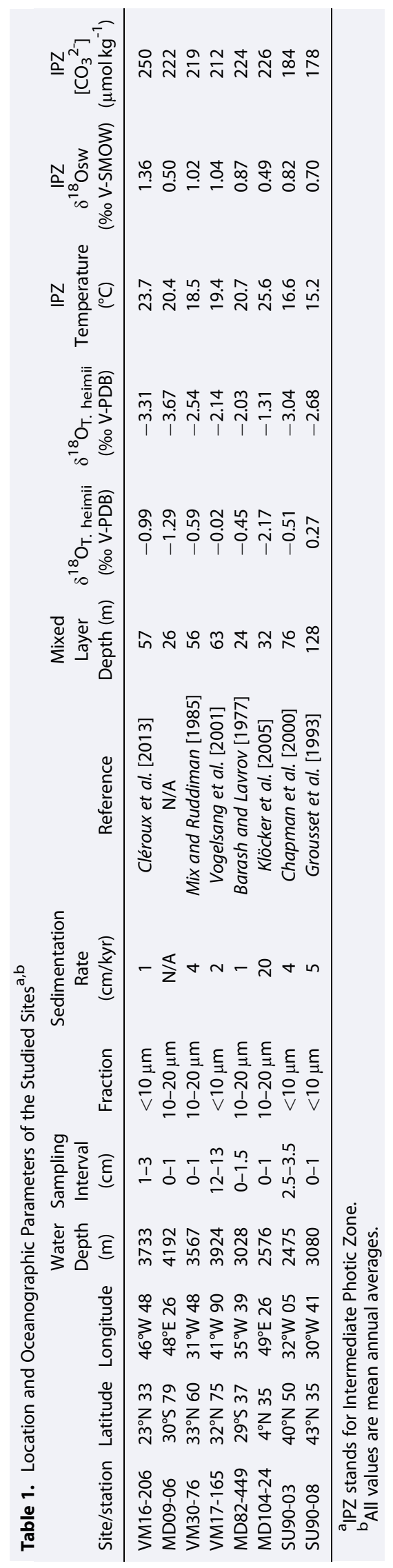

In gyre oceanographic regime, production of $T$. heimii is almost constant throughout the year [Zonneveld, 2004; Kohn et al., 2011]. In this study, we used mean annual temperature and $\delta^{18} \mathrm{O}_{\mathrm{sw}}$ to represent estimates of seawater physico-chemistry. Conversely, the offshore Somali MD104-24 site corresponds to warm waters with a pronounced upwelling-driven seasonality related to a monsoon regime [Fischer et al., 1996; Peeters et al., 2002; Schott et al., 2009]. In this region, the production of T. heimii is higher at the end of the SW monsoon (August to September) and at the beginning of the inter-monsoon (October to November), periods that correspond to the lowest and highest annual temperatures, respectively [Wendler et al., 2002a]. As most T. heimii shells were formed at either extreme of the temperature range, the mean annual temperature was assumed to integrate this variability. The seasonal variability of the $\delta^{18} \mathrm{O}_{\mathrm{sw}}$ is not known at this site.

\subsubsection{Microseparation Protocol}

Shells of $T$. heimii were physically isolated from sediments according to the protocol of Minoletti et al. [2001, 2009] based on cascade microfiltering steps. Approximately 1-2 $\mathrm{g}$ of bulk sample was suspended in deionized water, previously adjusted to $\mathrm{pH} 8$ by addition of ammonia to minimize calcite dissolution. Gentle stirring allowed complete disaggregation of the sediment. The suspension was first filtered through 315 and $160 \mu \mathrm{m}$ sieves and then through 40 and $20 \mu \mathrm{m}$ nylon nets to concentrate foraminifera and their fragments. Finally, the suspension was filtered onto $10 \mu \mathrm{m}$ pore size polycarbonate membranes (Millipore). Near-monospecific T. heimii assemblages were thus gathered from the 10 to $20 \mu \mathrm{m}$ interval. We chose a purity threshold of $90 \%$, below which fractions were regarded as not sufficiently purified. For those samples in which $T$. heimii assemblages were not pure, we applied a subsequent purification step based on strong ultrasonic treatment and selective breakage of particles by strong ultrasonic supply [Minoletti et al., 2009].

After separation, smear slides were prepared for each fraction using the technique described by Koch and Young [2007]. Relative abundances were estimated by counting at least 300 particles under cross-polarized light using a Zeiss Axioscope 40 microscope equipped with a $63 \times$ Plan-Neofluar objective.

Foraminiferal shells and fragments are the most abundant calcite particle in all fractions coarser than $20 \mu \mathrm{m}$. The fraction $<10 \mu \mathrm{m}$ contains coccoliths, such as Coccolithus pelagicus, Calcidiscus leptoporus, Gephyrocapsa spp., and Emiliania huxleyi and their fragments. Between these two size ranges, the $10-20 \mu \mathrm{m}$ fraction is composed mainly of $T$. heimii shells, with other rare calcareous components, such as foraminiferal fragments and rare lopadoliths of the coccolithophore Scyphosphaera apsteinii (Figures 2a and 2b). In samples MD09-06 and VM30-76, the proportion of $T$. heimii shells was lower than our target purity $(<90 \%)$, and foraminiferal fragments may contaminate the isotopic signal. In these cases, an additional purification method based short runs $(60 \mathrm{~s})$ of strong ultrasonic treatment [Minoletti 

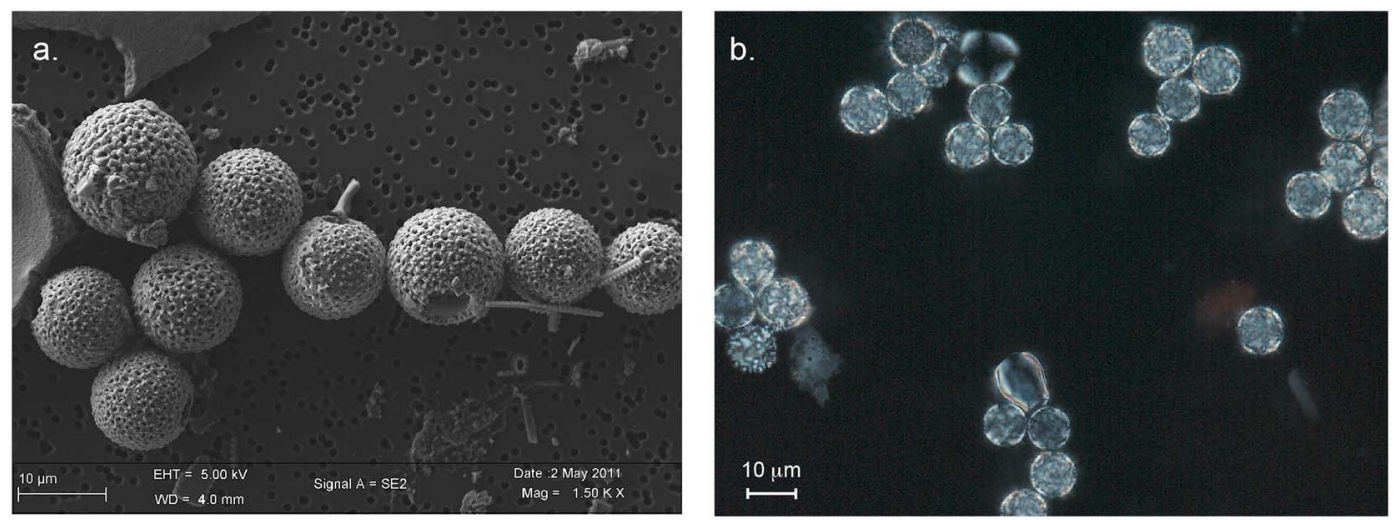

Figure 2. (a) SEM image and (b) smear-slide micrograph of a sedimentary T. heimii assemblage obtained from core top sample MD82-449 (Southern Atlantic Ocean). This near-monospecific T. heimii assemblage was obtained in the 10-20 $\mu \mathrm{m}$ fraction by the microfiltering protocol described in Minoletti et al. [2009].

et al., 2009] was applied, and it was possible to induce fragmentation of $T$. heimii shells while retaining foraminiferal fragments in their original size spectrum. Thoracosphaera fragments were subsequently collected in $\mathrm{a}<10 \mu \mathrm{m}$ fraction from the original $10-20 \mu \mathrm{m}$ fractions exposed to strong ultrasonic waves.

\subsection{Stable Isotope Measurements}

Carbonate stable isotopes were analyzed from about $80 \mu \mathrm{g}$ of culture residue or near-specific T. heimii assemblages from sediments on a VG Isoprime mass spectrometer. Samples were first cleaned using $10 \%$ hydrogen peroxide $\left(\mathrm{H}_{2} \mathrm{O}_{2}\right)$ to remove the organic matter, rinsed three times, and dried at $60^{\circ} \mathrm{C}$. In the instrument they were reacted with purified phosphoric acid $\left(\mathrm{H}_{3} \mathrm{PO}_{4}\right)$ at $90^{\circ} \mathrm{C}$. Calibration to V-PDB standard via NBS-19 was undertaken daily using the Marceau, a Carrara marble standard. Reproducibility of replicated standards was usually better than $0.05 \%$ ofor $\delta^{13} \mathrm{C}_{\mathrm{c}}$ and $0.1 \%$ o for $\delta^{18} \mathrm{O}_{\mathrm{c}}$. Carbonate data are expressed against the V-PDB standard for both oxygen and carbon isotopes (Tables 1 and 2).

Water sample measurements were made from the $\mathrm{CO}_{2}$ in the headspace equilibrated with a $0.5 \mathrm{~mL}$ aliquot in Exetainer tubes using Gas Bench II coupled to a Delta V Advantage mass spectrometer. Reproducibility of replicated standards was usually better than $0.2 \%$ for $\delta^{18} \mathrm{O}_{\mathrm{sw}}$. The oxygen isotope composition of water samples is expressed against V-SMOW standard (Table 1).

As $\delta^{13} \mathrm{C}$ of the DIC (predominantly $\mathrm{HCO}_{3}{ }^{-}$) changes with temperature [Mook et al., 1974], we assessed the carbon isotope composition of each medium for a given temperature using the equation from Lynch-Stieglitz et al. [1995], and assuming a $\delta^{13} \mathrm{C}$ of the DIC at $0 \%$ at $15^{\circ} \mathrm{C}$ [Hermoso et al., 2014]. Data are given in Table 2.

Table 2. Temperature, Specific Growth Rate, and Isotopic Data From the Culture Experiment ${ }^{a}$

\begin{tabular}{|c|c|c|c|c|c|c|}
\hline Code & Temperature $\left({ }^{\circ} \mathrm{C}\right)$ & $\mu\left(\right.$ day $\left.^{-1}\right)$ & $\delta^{18} \mathrm{O}_{\text {T. heimii }}(\% \circ \mathrm{V}-\mathrm{PDB})$ & $\delta^{13} \mathrm{C}_{\mathrm{T} . \text { heimii }}(\% \circ \mathrm{V}-\mathrm{PDB})$ & $\delta^{18} \mathrm{O}_{\text {medium }}(\%$ V-SMOW) & $\delta^{13} C_{\mathrm{DIC}}(\% \circ \mathrm{V}-\mathrm{PDB})$ \\
\hline $13 \mathrm{~A}$ & 13 & 0.23 & -0.25 & -6.36 & 0.67 & -1.20 \\
\hline $13 B$ & 13 & 0.24 & -0.01 & -6.03 & 0.67 & -1.20 \\
\hline $15 \mathrm{~A}$ & 15 & 0.26 & -0.16 & -6.62 & 0.69 & -1.38 \\
\hline $15 B$ & 15 & 0.28 & -0.32 & -6.83 & 0.69 & -1.38 \\
\hline $17 \mathrm{~A}$ & 17 & 0.29 & -0.12 & -5.79 & 0.65 & -1.56 \\
\hline $17 \mathrm{~B}$ & 17 & 0.34 & -0.37 & -6.14 & 0.65 & -1.56 \\
\hline $20 \mathrm{~A}$ & 20 & 0.38 & -1.24 & -4.23 & 0.69 & -1.84 \\
\hline $20 B$ & 20 & 0.38 & -1.14 & -4.49 & 0.69 & -1.84 \\
\hline $23 \mathrm{~A}$ & 23 & 0.52 & -1.60 & -4.32 & 0.70 & -2.12 \\
\hline $23 B$ & 23 & 0.53 & -1.72 & -4.63 & 0.70 & -2.12 \\
\hline $25 \mathrm{~A}$ & 25 & 0.50 & -2.16 & -3.92 & 0.68 & -2.30 \\
\hline $25 B$ & 25 & 0.48 & -2.25 & -4.07 & 0.82 & -2.30 \\
\hline $27 \mathrm{~A}$ & 27 & 0.46 & -2.03 & -3.81 & 0.67 & -2.48 \\
\hline $27 B$ & 27 & 0.46 & -1.94 & -3.83 & 0.67 & -2.48 \\
\hline
\end{tabular}

${ }^{\mathrm{a}}$ Isotope compositions of culture residues and $\delta^{18} \mathrm{O}$ of the culturing medium were measured for all temperatures. Carbon isotope compositions of the DIC for each temperature derived from the measurement at $15^{\circ} \mathrm{C}$ with $\delta^{13} \mathrm{C}$ of $\mathrm{DIC}=0 \%$ o [Hermoso et al., 2014]. For each other temperature, we used the equation given by Lynch-Stieglitz et al. [1995] to account for the temperature dependence on $\delta^{13} \mathrm{C}$ of DIC. 


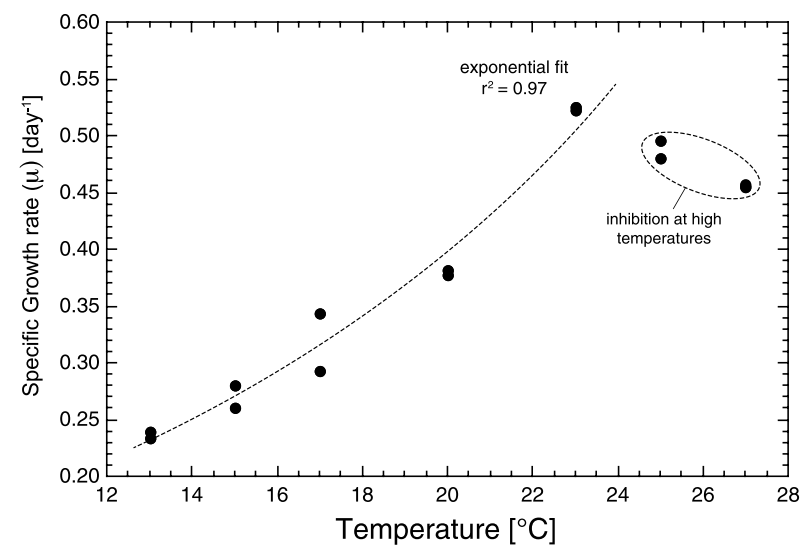

Figure 3. Specific growth rate of cultured T. heimii (strain RCC 1511) with respect to temperature. Growth rates exponentially increase up to an ecological optimum at $\sim 24^{\circ} \mathrm{C}$, confirming the affinity for relatively warm waters of this species, although highest temperatures seem to inhibit cell division.

\subsection{Expression of Results}

In the present study, the composition of $T$. heimii calcite is expressed for both isotope systems by using the " $\delta-\delta$ " notation, i.e., $\delta^{18} \mathrm{O}_{\mathrm{c}}-\delta^{18} \mathrm{O}_{\mathrm{sW}}(\mathrm{V}-\mathrm{PDB}-\mathrm{V}-\mathrm{SMOW})$ and

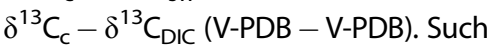
isotopic values do not correspond to fractionation coefficients but represent convenient estimates routinely used in paleoceanography to normalize microfossil geochemistry and allows comparison between regions with different seawater chemistries. Comparison with an inorganic reference is achieved via the offset of $T$. heimii calcite with the equilibrium calcite calculated after the equation of Kim and O'Neil [1997] approximated to quadratic expression by Bemis et al. [1998] for oxygen and after the equation of Romanek et al. [1992] for carbon.

Two corrections were applied to the intercept of the inorganic calcite $\delta^{18} \mathrm{O}$ equation (see Candelier et al. [2013]). The effect of $\mathrm{pH}$ on ${ }^{18} \mathrm{O}$ apparent fractionation consists of a $\delta^{18} \mathrm{O}$ decrease of $1.42 \%$ for an increase of 1 pH unit [Spero et al., 1997; Zeebe, 2001; Watkins et al., 2014]. As the work by Kim and O'Neil [1997] was based on experiments conducted at $\mathrm{pH} 7.8$ and our T. heimii were grown at $\mathrm{pH} 8.2$, a correction of -0.568 was applied. In addition, we reverse the $\mathrm{d}^{18}$ Osw conversion from V-PDB to V-SMOW scale by subtracting $0.27 \%$ [Hut, 1987] from the intercept. This adjustment is necessary to present all data on the same scale, in the present case in V-SMOW, as is common practice in the calcareous phytoplankton literature. The resulting inorganic reference equation is as follows:

$$
\left.\delta^{18} \mathrm{O}_{\mathrm{c}[\% \mathrm{~V}-\mathrm{PDB}]}-\delta^{18} \mathrm{O}_{\mathrm{sw}[\% \mathrm{~V}-\mathrm{SMOW}]}=-0.211 \times \mathrm{T}_{\left[{ }^{\circ} \mathrm{C}\right]}+3.410-0.568-0.27\right)
$$

\section{Results}

\subsection{Algal Growth and Medium Drift}

Specific growth rate $(\mu)$ increased from 13 to $23^{\circ} \mathrm{C}$, with an exponential trend from 0.24 to 0.52 day $^{-1}$ $\left(r^{2}=0.97\right)$ (Figure 3). Growth rates diminished at 25 and $27^{\circ} \mathrm{C}$, possibly indicating an ecological optimum at $24^{\circ} \mathrm{C}$ for this strain and applied experimental setup (light and nutrient levels). Final cell concentrations at the end of the experiments were between 4000 and 16,000 cells per mL. Even the highest cell density corresponds to very little utilization of the DIC resource in the culture medium. A conservative estimate of $5 \%$ DIC drawdown is obtained by considering 2000 pg C per cell [Young and Ziveri, 2000]. This represents significantly lower yields compared to the end of the culture study of Zonneveld et al. [2007]. In our experiments, the typical drift in $\mathrm{pH}$ measured at the end of the experiments was less than 0.1 unit owing to our very dilute cell concentration strategy. This stability of the growth medium testifies for the stable composition of the carbonate system that the cells were subjected to throughout the experiments, with similar conditions at the beginning and the end of the experiments.

\subsection{Oxygen Isotope Values of Culture Residues}

Growth temperature strongly influences the oxygen isotope composition of $T$. heimii calcite. Over the 13 to $27^{\circ} \mathrm{C}$ interval, the range in $\delta^{18} \mathrm{O}_{c}$ was $\sim 2.2 \%$ with isotopic ratios linearly decreasing with temperature, as expected from equilibrium prediction (Figure 4). The replicates were in good agreement with a mean standard deviation on the order of $0.10 \%$, indicating that obtained magnitudes of fractionation estimated from $\delta_{c}-\delta_{s w}$ values are reproducible and show a very strong linear relationship with temperature $\left(r^{2}=0.91\right)$. The equation linking oxygen isotope composition and temperature is:

$$
\delta^{18} \mathrm{O}_{\mathrm{c}[\% \mathrm{~V}-\mathrm{PDB}]}-\delta^{18} \mathrm{O}_{\mathrm{sw}[\% \mathrm{~V}-\mathrm{SMOW}]}=-0.17 \times \mathrm{T}_{\left[{ }^{\circ} \mathrm{C}\right]}+1.52\left(\mathrm{r}^{2}=0.91\right)
$$




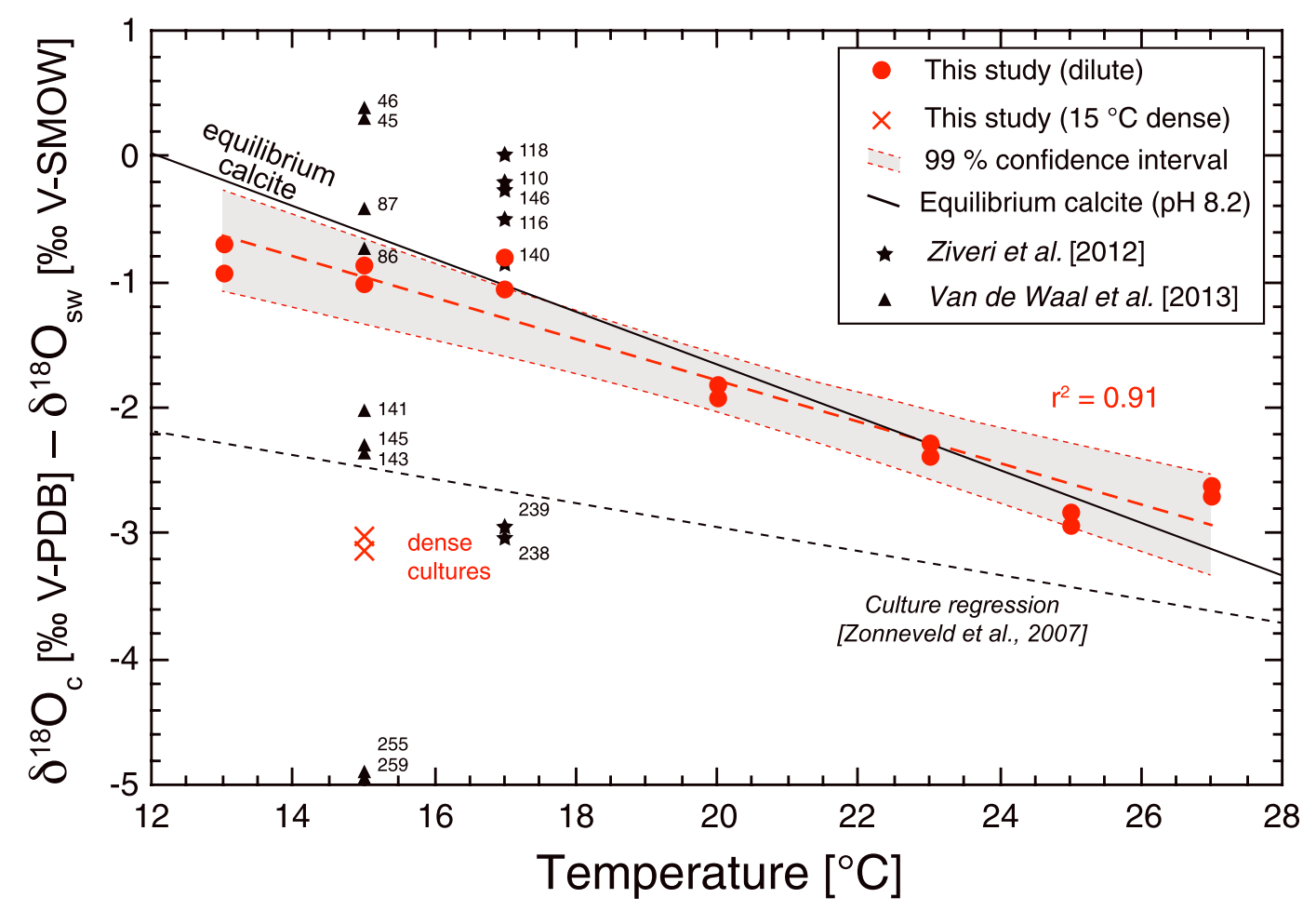

Figure 4. Oxygen isotope composition of $T$. heimii calcite (expressed as $\delta^{18} \mathrm{O}_{\text {T.heimii }}$ [\%o V-PDB] $-\delta^{18} \mathrm{O}_{\text {sw [\%o V-SMOW] }}$ ) versus temperature in laboratory culture experiments. Data from dilute bioassays are represented by red circles. High cell density $15^{\circ} \mathrm{C}$ batch cultures (2\%o isotopically lighter than the very dilute $15^{\circ} \mathrm{C}$ assay) are indicated by red crosses. Overall, the data show a very good linear regression coefficient $\left(r^{2}=0.91\right)$. The equilibrium calcite line was calculated after Kim and $\mathrm{O}^{\prime} \mathrm{Neil}$ [1997] and adjusted for $\mathrm{pH} 8.2$ (see equation (1) in text). At temperatures greater than $15^{\circ} \mathrm{C}$, the agreement with the equilibrium reference is remarkably good, while at lower temperatures, $\delta^{18} \mathrm{O}$ values are offset by about $1 \%$ o toward negative values. The culture regression of Zonneveld et al. [2007] is indicated with the dashed line; other culture data sets are indicated with black stars [Ziveri et al., 2012] and black triangles [Van de Waal et al., 2013]. Numbers next to symbols correspond to the carbonate ion concentrations in the medium expressed in $\mu \mathrm{mol} \mathrm{kg}_{\mathrm{sw}}{ }^{-1}$. For comparison, our cultures were grown at $\left[\mathrm{CO}_{3}{ }^{2-}\right]$ of $\sim 250 \mu \mathrm{mol} \mathrm{kg} \mathrm{sw}^{-1}$.

The root mean square error (RMSE) of the distribution $(n=14)$ indicates a residual of about $1.6^{\circ} \mathrm{C}$ indicating the good accuracy of the culture calibration. A $-2 \%$ offset was recorded between the early and late exponential phase data points at $15^{\circ} \mathrm{C}$ (Figure 4). Taken at face value, this offset would represent an unrealistic $\sim 12^{\circ} \mathrm{C}$ discrepancy. This result illustrates that performing very dilute cultures in batch is a prerequisite for measuring meaningful ${ }^{18} \mathrm{O}$ fractionation factors. It is worth noting that the oxygen isotope measurements obtained for temperatures lower than $17^{\circ} \mathrm{C}$ depart from the inorganic reference. Disregarding the two lowest temperatures, also corresponding to minimum growth rate of $T$. heimii, our culture calibration is parallel and indistinguishable from the inorganic reference (Figure 4):

$$
\delta^{18} \mathrm{O}_{\mathrm{c}[\% \mathrm{~V}-\mathrm{PDB}]}-\delta^{18} \mathrm{O}_{\mathrm{sw}[\% \mathrm{~V}-\mathrm{SMOW}]}=-0.19 \times \mathrm{T}_{\left[{ }^{\circ} \mathrm{C}\right]}+2.09\left(\mathrm{r}^{2}=0.86\right)
$$

The RMSE corresponds to the "internal" reliability of the calibration, in the sense that it is based on the distribution of measurements and their degree of scattering with respect to the linear regression line. The same approach can be used to assess an "external" uncertainty of $\delta^{18} \mathrm{O}$ composition in T. heimii compared to the inorganic calcite (equation (1)). The RMSE using predicted values that derive from equation (1) is $3.0^{\circ} \mathrm{C}(n=14)$. Not surprisingly, the lowest temperatures $\left(13\right.$ and $\left.15^{\circ} \mathrm{C}\right)$ correspond to maximal residuum of the population (Figure 4). Disregarding these coldest temperature, RMSE in the range of $17-27^{\circ} \mathrm{C}$ is significantly reduced and quantified to $2.3^{\circ} \mathrm{C}(n=10)$. These contrasting vital effects for oxygen isotopes on both sides of the $17^{\circ} \mathrm{C}$ cutoff temperature challenge the univocal assignment of $T$. heimii to an isotopically "light group" [Zonneveld et al., 2007; Ziveri et al., 2012; Van de Waal et al., 2013]. However, our data support a relatively light isotopic composition at $15^{\circ} \mathrm{C}$, as previously documented at this temperature [Hermoso et al., 2014]. 


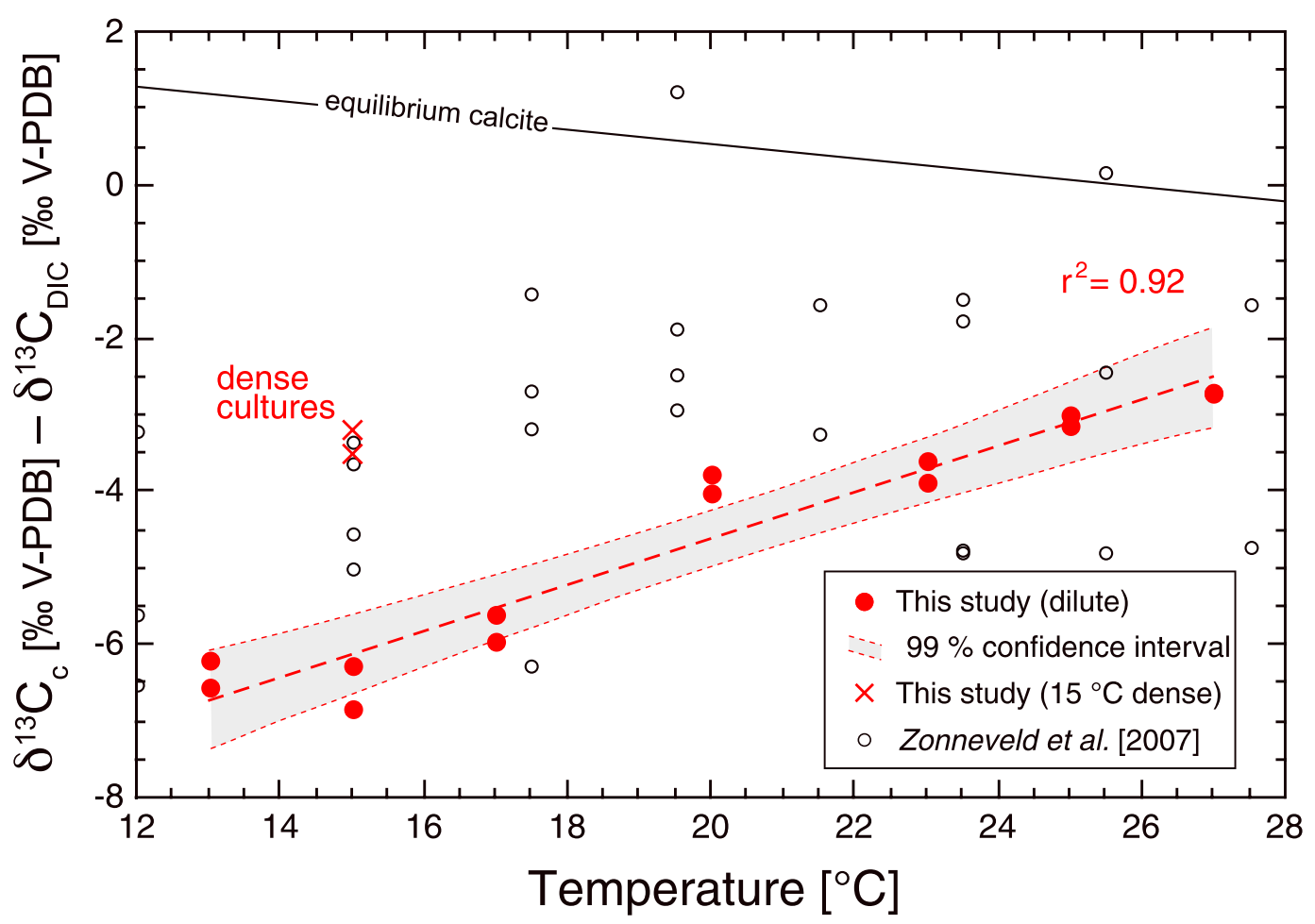

Figure 5. Carbon isotope composition of cultured T. heimii calcite (expressed as $\delta^{13} C_{\text {T.heimii }}$ [\%o V-PDB] $-\delta^{13} C_{\text {DIC [\%o V-PDB] }}$ ) versus temperature. Key for symbols in inset. High cell density $15^{\circ} \mathrm{C}$ batch cultures are isotopically $2 \%$ heavier than the very dilute $15^{\circ} \mathrm{C}$ assay. The data show a good linear regression coefficient $\left(r^{2}=0.86\right)$. Carbon isotope composition of equilibrium calcite is calculated from $\delta^{13} C_{\text {DIC }}$ (Table 2) by applying the equation of Romanek et al. [1992].

\subsection{Carbon Isotope Values of Culture Residues}

The $\delta^{13} C_{C}-\delta^{13} C_{D I C}$ values of $T$. heimii are linearly correlated with temperature $\left(r^{2}=0.92\right)$ (Figure 5). Because temperature and $\delta^{18} \mathrm{O}_{\mathrm{c}}$ are also correlated, there was a strong relationship between carbon and oxygen values $\left(r^{2}=0.86\right)$. We measured very negative $\delta^{13} C_{c}$ for $T$. heimii shells that fall between the composition of equilibrium calcite (calculated after Romanek et al. [1992]) and that of aqueous $\mathrm{CO}_{2}$ assumed to be the substrate assimilated by the cell (around -10.2\%o) calculated after Lynch-Stieglitz et al. [1995].

\subsection{Oxygen Isotope Values of Microseparated $T$. heimii Fractions}

For T. heimii fractions, $\delta^{18} \mathrm{O}_{\mathrm{c}}-\delta^{18} \mathrm{O}_{\mathrm{sw}}$ values range from $-0.43 \%$ at $15.2^{\circ} \mathrm{C}$ for North Atlantic site SU90-08 to $-2.66 \%$ at $25.6^{\circ} \mathrm{C}$ for site MD104-24 (Offshore Somalia) and are negatively correlated to temperature (Figure 6). The equation linking oxygen isotope fractionation to temperature in the core top approach is:

$$
\delta^{18} \mathrm{O}_{\mathrm{c}[\% \mathrm{~V}-\mathrm{PDB}]}-\delta^{18} \mathrm{O}_{\mathrm{sW}[\% \mathrm{~V}-\mathrm{SMOW}]}=-0.19 \times \mathrm{T}_{\left[{ }^{\circ} \mathrm{C}\right]}+2.16\left(\mathrm{r}^{2}=0.82\right)
$$

Core top fractions are in very good agreement with culture data over the entire investigated temperature range, i.e., including the lowest temperature at $15.2^{\circ} \mathrm{C}$. When plotted on the same graph, the samples from Zonneveld [2004] that where of comparable purity to the present study ( $>90 \%)$ confirm this regression line while less pure $T$. heimii fractions exhibit scattered and overall, more positive $\delta^{18} \mathrm{O}_{c}$ values (Figure 6).

\subsection{Carbon Isotope Values of Microseparated $T$. heimii Fractions}

The $\delta^{13} C_{c}$ values of $T$. heimii fractions exhibit relatively light values, ranging from $-1.31 \%$ o to $-3.67 \%$ o (Table 1). This observation is in agreement with data from cultured T. heimii shells (Figure 5) and with evidence from the geological record [Friedrich and Meier, 2003; Kohn et al., 2011]. As relatively easily done for the oxygen isotope system (see section 2.2.2.), retrieving oceanic $\delta{ }^{13} \mathrm{C}$ of DIC relevant for T. heimii found in core tops has been found to be challenging. First, the coverage and resolution of available databases for 


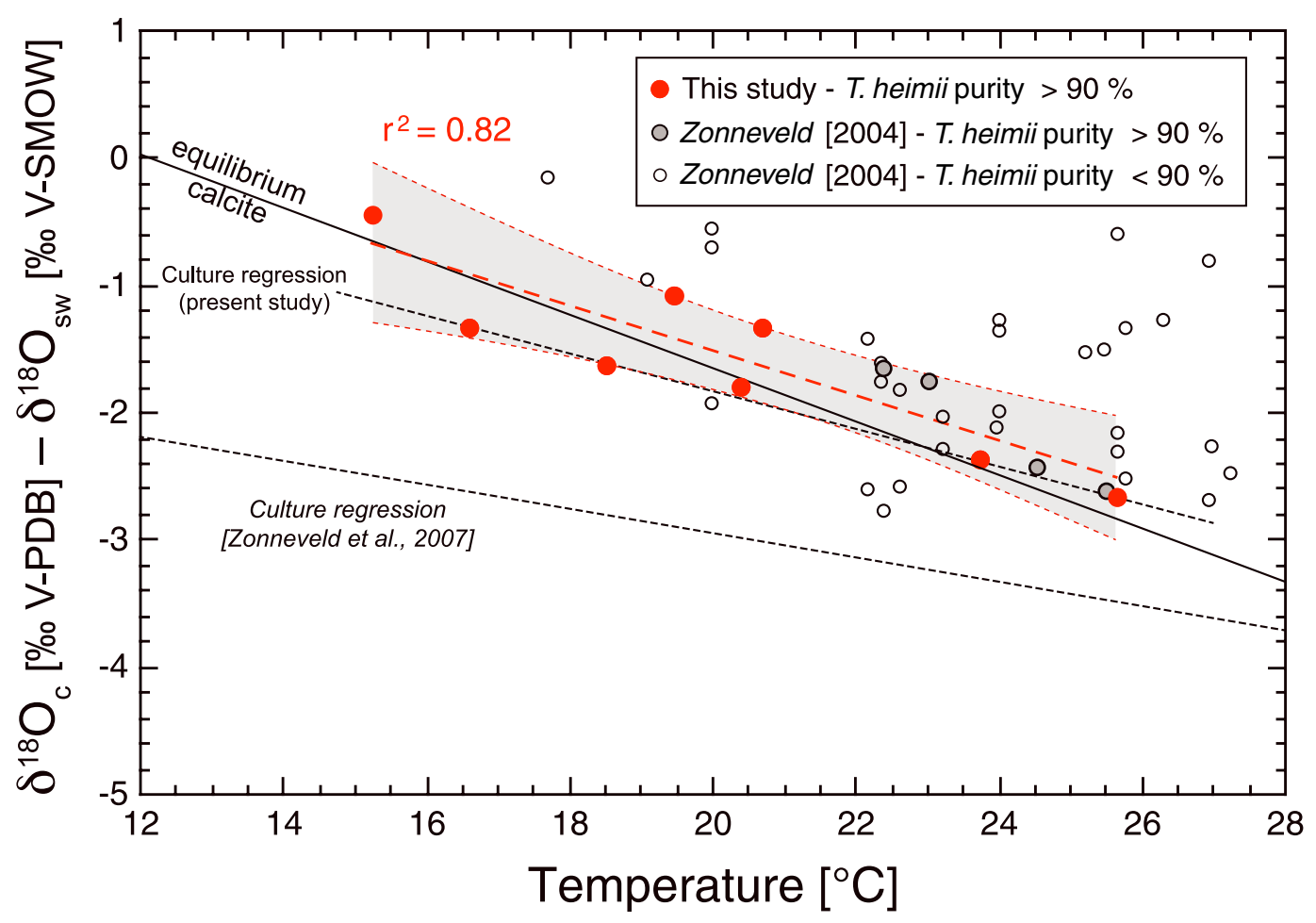

Figure 6. Oxygen isotope composition of T. heimii calcite (expressed as $\delta^{18} \mathrm{O}_{\text {Theimii }}$ [\% V-PDB] $-\delta^{18} \mathrm{O}_{\text {sw }}$ [\%o V-SMOW]) versus temperature in core tops. Thoracosphaera fractions from Zonneveld [2004] are shown by gray circles (purity $>90 \%$ ) and open circles (purity $<90 \%$ ). The oxygen isotope composition of $T$. heimii microseparated fractions is highly correlated with temperature of the intermediate photic zone $\left(r^{2}=0.82\right.$-linear regression is depicted by a thick red dashed line $)$ and close to that of equilibrium calcite. The $99 \%$ confidence interval indicated by the gray shaded area shows a \pm 0.5 dispersion of the points with respect to the overall trend. The core top calibration equation has a slope and intersect that are indistinguishable from those of culture experiment (this study). The only appreciable difference between our culture and core top calibration relies on the lowest temperature data points. The offset from equilibrium toward negative $\delta^{18} \mathrm{O}$ values $<17^{\circ} \mathrm{C}$ is not seen in core top data.

present-day carbon isotope of DIC in seawater are rather scarce [Gruber et al., 1999]. Second, T. heimii shells laid down on the seafloor were produced before the infusion of isotopically light carbon into the surface waters (as referred to as the Suess effect). Last, $T$. heimii thrives in the intermediate photic zone layer while available data correspond to surface waters. As a result, data from present-day waters do not accurately account for $\delta^{13} \mathrm{C}_{\mathrm{DIC}}$ values to which $T$. heimii from our microseparated fractions were exposed to.

These methodological and conceptual issues prevent us to express carbon isotope fractionation using the ${ }^{1} \delta^{13} C_{C}-\delta^{13} C_{D I C}$ " notation. Consequently, taking $T$. heimii $\delta^{13} C_{c}$ as a proxy for carbon isotope fractionation in core tops can only be ascertained if all aforementioned parameters are not themselves temperature dependent. Estimates of paleo- $\delta{ }^{13} C_{\text {DIC }}$ that would reflect the composition of $T$. heimii's depth habitat could be made using the carbon isotope signature of the foraminifera Globorotalia menardii or Neogloboquadrina dutertrei extracted from the same core top sediments. Species-specific coefficient allowing conversion of foraminiferal $\delta^{13} C_{C}$ into $\delta^{13} C_{D I C}$ as determined by Spero et al. [2003] might be applied to constrain $\delta^{13} C_{c}$ of the intermediate photic zone. Unfortunately, we did not have access to the coarse fraction of our core top sediments, nor found previously-published $\delta^{13} \mathrm{C}$ of foraminifera for these sites. With all these problems in mind, we refrained from interpreting sedimentary $\delta^{13} \mathrm{C}_{c}$ values of $T$. heimii. Nevertheless, raw isotopic data are presented in Table 1.

\section{Discussion}

\subsection{Oxygen Isotope Composition: “Light" Versus "Equilibrium" Group?}

Our culture data indicate that $T$. heimii precipitates calcite in near-equilibrium conditions (Figure 4). The main source of DIC assimilation in T. heimii has been demonstrated to be $\mathrm{CO}_{2}$ [Van de Waal et al., 2013]. The fact 
that $\delta^{18} \mathrm{O}_{\mathrm{c}}$ was not shifted toward more positive values indicates that the very heavy oxygen isotope composition of $\mathrm{CO}_{2}\left(\sim+7 \%\right.$ o with respect to $\mathrm{HCO}_{3}{ }^{-}$[Zeebe, 1999]) is not preserved in calcite produced by T. heimii. This implies total re-equilibration of the oxygen isotope system $\left(\mathrm{H}_{2} \mathrm{O} / \mathrm{CO}_{2}-\mathrm{HCO}_{3}{ }^{-}-\mathrm{CO}_{3}{ }^{2-}\right)$. In solution, total re-equilibration is attained within approximately $12 \mathrm{~h}$ at $15^{\circ} \mathrm{C}$ [Zeebe and Wolf-Gladrow, 2001].

The oxygen isotope system of fast growing coccolithophores such as $E$. huxleyi is not completely re-equilibrated at time of calcification and their calcite therefore reflects to some extent the isotopic composition of the isotopically heavy $\mathrm{CO}_{2}$ source [Hermoso et al., 2014]. This thermodynamic feature typifies the so-called "heavy group" [Dudley et al., 1986]. The near equilibrium $\delta^{18} \mathrm{O}_{\mathrm{c}}$ of $T$. heimii might be explained by the proven presence of carbonic anhydrase inside the cell and in the boundary layer [Van de Waal et al., 2013], which speeds up the re-equilibration between DIC and $\mathrm{H}_{2} \mathrm{O}$ [Uchikawa and Zeebe, 2012]. Additionally, a long residence time of the intracellular DIC pool between assimilation and calcification could account for equilibrium composition, as for the coccolithophore Coccolithus pelagicus [Hermoso et al., 2014], which, like T. heimii, has a relatively slow growth rate.

At low temperatures ( 13 and $15^{\circ} \mathrm{C}$ ), offsets from equilibrium of about $-1 \%$ o were recorded in $T$. heimii calcite, as observed by Hermoso et al. [2014]. Over this temperature range, T. heimii can hence be assigned to the isotopically "light group", like the coccolithophore Calcidiscus leptoporus. The change in oxygen isotope values at the lowest temperatures corresponds to the ecological lower limit for this species in terms of temperature tolerance (Figure 3). Lower growth rate would leave more time for thermodynamic re-equilibration of the DIC with $\mathrm{H}_{2} \mathrm{O}$, but this process is also slower at low temperatures, so an explanation based on kinetics of the oxygen isotope system can be ruled out.

From a chemical point of view, $\delta^{18} \mathrm{O}_{\mathrm{c}}$ lower than equilibrium can result from a higher relative proportion of $\mathrm{CO}_{3}{ }^{2-}$ compared to $\mathrm{HCO}_{3}{ }^{-}$at the site of calcification (relative to the ratio of the external fluid) or from kinetic effect [Watkins et al., 2014]. This change in the DIC system would be accompanied by increased pH. We hypothesize that a less active carbon concentrating mechanism and/or less intense calcification at low temperature could account for higher $\mathrm{pH}$. With a lowered net $\mathrm{CO}_{2}$ flux, as evidenced by limited growth rate at low temperature, calcification would occur in a less acidic environment. Under this assumption, calcite grown at lower temperatures would reflect the higher $\mathrm{pH}$ and concomitant higher abundance of $\mathrm{CO}_{3}{ }^{2-}$ with respect to $\mathrm{HCO}_{3}{ }^{-}$and therefore would have lower oxygen isotope values. An alternative hypothesis is that the reequilibration time is not achieved completely below $17^{\circ} \mathrm{C}$ due to the reduced activity of carbonic anhydrase at low temperature. Further biogeochemical work is required to test these hypotheses, especially to characterize passive diffusion of $\mathrm{CO}_{2}$ versus $\mathrm{HCO}_{3}{ }^{-}$uptake in $\mathrm{T}$. heimii and more broadly the carbon concentrating mechanisms (or CCMs) under a range of temperatures.

\subsection{Comparison With Previous Culture Studies}

4.2.1. Implications of the Culture Technique for the Magnitude of the Vital Effect

The culture strategy (dilute versus dense) has a strong effect on the isotopic composition of T. heimii calcite. This point is well illustrated by the batch cultures at $15^{\circ} \mathrm{C}$ that reached the late exponential phase with cell division being hampered by unfavorable living conditions. Low $\delta^{18} \mathrm{O}_{\mathrm{c}}$ are unlikely to be the consequence of changed $\delta^{18} \mathrm{O}$ of the medium during growth, as initial and final measurements were within analytical error. Rather, we explain this drift by an altered chemistry of the medium with substantial elevation of $\mathrm{pH}$ due to the consumption of $\mathrm{CO}_{2}$. This "culture artifact" may hence correspond to the combination of reduced $\left[\mathrm{CO}_{2 \mathrm{aq}}\right]$ and high $\mathrm{pH}$, at which enzymatic activity, including those involved in the CCMs, is ineffective. Other environmental parameters could be involved in such large shifts toward negative $\delta^{18} \mathrm{O}_{\mathrm{c}}$ values, including the effect of $\mathrm{pH}$ [Zeebe, 1999, 2001] and potentially the influence of reduced light and nutrient levels.

4.2.2. The Pioneering Work of Zonneveld et al. [2007]

Zonneveld et al. [2007] performed an extensive culture campaign investigating ${ }^{18} \mathrm{O}$ fractionation in T. heimii under a wide range of temperatures (Figure 1). They documented the evolution of carbonate chemistry during growth, which can be used to better interpret the oxygen isotope compositions of $T$. heimii calcispheres produced in the laboratory. The authors calculated a linear equation for ${ }^{18} \mathrm{O}$ fractionation according to temperature from their culture examination of two strains of $T$. heimii. They grew $T$. heimii using an initial $\mathrm{pH}$ of 8.0, which is $0.2 \mathrm{pH}$ unit higher than in our experimental condition.

In the culture study of Zonneveld et al. [2007], the $\mathrm{pH}$ drifts were significant, by $+0.4 \mathrm{pH}$ unit. This drift is similar to that we observed in our late exponential assays. As cell density and hence calcification, follow an 
exponential curve, the results are more representative of the final conditions rather than the controlled initial conditions in a batch culture. Combining the duration of the batch experiments, the volume of culture medium, the biomass harvested and the drift in $\mathrm{pH}$, this would suggest that the culture assays presented by Zonneveld et al. [2007] were not carried out at very low cell concentration, although it is claimed that the cultures were still in the exponential growth phase at the end of the experiments.

Carbon isotope ratios measured on T. heimii cultured by Zonneveld et al. [2007] and our dense $15^{\circ} \mathrm{C}$ batches provide compelling evidence for a culture artifact with very high $\delta^{13} \mathrm{C}_{\mathrm{c}}$ having been reported. With a fairly high degree of DIC $\left(\mathrm{CO}_{2}\right)$ utilization during the course of experiments, $\delta^{13} \mathrm{C}$ of the medium is more strongly affected by ${ }^{12} \mathrm{C}$ fixation into organic matter and calcite is formed from a DIC pool with high $\delta^{13} \mathrm{C}_{\mathrm{DIC}}$ values [Hinga et al., 1994; Hermoso et al., 2014].

Taken together, these observations indicate that the non-equilibrium $\delta^{18} \mathrm{O}_{\mathrm{c}}$ of $T$. heimii cultured by Zonneveld et al. [2007] are likely to have been induced by a reservoir effect, as was the case in our dense $15^{\circ} \mathrm{C}$ cultures. Candelier et al. [2013] reevaluated the magnitude of ${ }^{18} \mathrm{O}$ vital effect for the coccolithophore Calcidiscus leptoporus reported in previous studies by undertaking very dilute batch cultures. The earlier work by Dudley et al. [1986] reported $\delta^{18} \mathrm{O}_{\mathrm{c}} \sim 1.5 \%$ o lighter than the data of Candelier et al. [2013]. It therefore appears that both coccolithophores and calcareous dinoflagellates are similarly affected by the culture artifact induced by high cell concentrations. This similarity between groups is also best explained by a reservoir effect with $\left[\mathrm{CO}_{2 \mathrm{aq}}\right]$ becoming limiting with growth, while we acknowledge that there are many other parameters of the growth medium that may simultaneously drift (total alkalinity, $\left[\mathrm{Ca}^{2+}\right],[\mathrm{DIC}],\left[\mathrm{CO}_{3}{ }^{2-}\right]$, and $\mathrm{pH}$ ).

4.2.3. Perturbation Experiments of Ziveri et al. [2012] and Van de Waal et al. [2013]

Among the species investigated by Ziveri et al. [2012], T. heimii records the highest dependence of $\delta^{18} \mathrm{O}$ on the carbonate ion concentration. Over a range between 50 and $250 \mu \mathrm{mol} \mathrm{kg}_{\mathrm{sw}}{ }^{-1}$ of $\mathrm{CO}_{3}{ }^{2-}$ in the culture medium, the change in $\delta^{18} \mathrm{O}_{\mathrm{c}}$ was as high as $5 \%$ o for a given temperature (Figure 4). With less $\mathrm{CO}_{3}{ }^{2-}$ in the external medium, oxygen isotopes are shifted toward positive $\delta^{18} \mathrm{O}$ values, whereas with more carbonate ion availability and therefore relatively higher saturation state with respect to calcite, the isotopic composition of $T$. heimii calcite was close to that of $\mathrm{CO}_{3}{ }^{2-}$. In coccolithophores such as C. leptoporus, this effect can be induced by relatively high $\mathrm{pH}$ at the site of calcification in the coccolith vesicle and may explain the $\sim 1.5 \%$ offset from equilibrium calcite in $\delta^{18} \mathrm{O}$ values [Ziveri et al., 2012; Candelier et al., 2013].

The concept of a pH effect on oxygen isotope composition was originally introduced to describe a purely inorganic phenomenon [McCrea, 1950] and later used to describe observations in planktic foraminifera [Bemis et al., 1998; Zeebe, 1999]. Due to the distinct $\delta^{18} \mathrm{O}$ values between the DIC species in seawater, there is a great effect via the relative proportion of DIC species on $\delta^{18} \mathrm{O}$ of calcite (see 2.4.). To investigate this $\mathrm{pH}$ effect, Ziveri et al. [2012] bubbled $\mathrm{CO}_{2}$ in the culture medium. Similarly, with an oceanic acidification perspective, Van de Waal et al. [2013] used the same technique to reach target $\mathrm{CO}_{3}{ }^{2-}$ concentrations. As a result, the isotopic composition of calcite is influenced by the relative proportion of $\mathrm{CO}_{3}{ }^{2-}$ with respect to $\mathrm{CO}_{2}+\mathrm{HCO}_{3}{ }^{-}$, but also by the total amount of DIC available for the cell. These absolute and relative changes of $\mathrm{CO}_{2}$ explain why the response in oxygen isotope values in manipulated coccoliths is much greater than observed for the sole $\mathrm{pH}$ effect measured on foraminifera [Spero et al., 1997]. By using an alternative method by which target $\mathrm{CO}_{3}{ }^{2-}$ concentrations were obtained through addition of strong acid or base, meaning the total amount of DIC remained unchanged, Ziveri et al. [2012] recorded a pH effect (referred as to a carbonate ion effect in their study) on coccolithophore species similar to that previously reported for foraminifera [Spero et al., 1997; Zeebe, 1999] yet lower than that measured on T. heimii.

From these perturbation experiments, it is thus difficult to establish a direct link between $\mathrm{CO}_{3}{ }^{2-}$ concentrations, $\mathrm{pH}$, and $\delta^{18} \mathrm{O}$ change with temperature, as more than one parameter was modified. Our experiments were not intended to examine the effect of the status of the carbonate system on $\delta^{18} \mathrm{O}$, but rather to investigate the temperature record in conditions as close as possible to the natural environment, i.e., keeping all other parameters constant by using very dilute batch cultures.

\subsection{Reconciled Culture and Core Top Data}

\subsubsection{Temperature and $\delta^{18} \mathrm{O}$ of Dinoflagellate Calcite}

There is a good concordance between culture and core top data in our study (Figures 4 and 6). In both data sets, strong linear correlation coefficients demonstrate the foremost control of temperature on oxygen isotope composition in T. heimii calcite. This concordance in the slopes and intersects of the equations 
(equations (2)-(4)) means that our calibration is transferable to natural environments and that $\delta^{18} \mathrm{O}$ of $T$. heimii calcite may be used as a robust paleothermometer for assessing seawater temperatures of the intermediate photic zone.

From our culture and core top studies, it is clear that calcification of T. heimii is made in near isotopic equilibrium with ambient seawater for the oxygen isotopes. This absence of apparent vital effect potentially indicates a relatively low degree of biological control on calcification in T. heimii for this isotopic system. This geochemical observation may be related to the suggested partially external mode of biomineralization in T. heimii [Tangen et al., 1982; Inouye and Pienaar, 1983; Gussone et al., 2010].

Below $17^{\circ} \mathrm{C}, \delta^{18} \mathrm{O}$ values of the calcite of cultured $T$. heimii are slightly offset from equilibrium $(\sim-1 \%$ o), but this departure was not recorded in core top data. Indeed, at $15.2^{\circ} \mathrm{C}$, which is the mean annual temperature of site SU90-08, T. heimii exhibited equilibrium $\delta^{18} \mathrm{O}$ values. This slight discrepancy would suggest that the calcite of cultured $T$. heimii is isotopically shifted due to a process that is not operating in the natural environment. Further biogeochemical work would be useful to confirm the existence of this differential vital effect and to understand its origin. Examining core tops where calcification took place in temperatures colder than $15^{\circ} \mathrm{C}$ would also help reconcile datasets and confirm whether $T$. heimii belongs to the isotopically "light group" at low temperature. Nevertheless, T. heimii mainly thrives in low-latitude waters characterized by temperature corresponding to the range where its $\delta^{18} \mathrm{O}$ composition is not offset [Karwath et al., 2000; Kohn and Zonneveld, 2010]. Considering the long-term cooling of the Cenozoic, it could be inferred that temperatures of $T$. heimii habitat in the pelagic environment have never been lower than $15^{\circ} \mathrm{C}$. As such, the possible limitation of our calibration may have no effect on the applicability of paleotemperature reconstruction with a geological perspective.

In their attempt to reconstruct seawater temperatures over the last $45 \mathrm{ka}$, Kohn et al. [2011] measured $\delta^{18} \mathrm{O}_{\mathrm{c}}$ of T. heimii and two planktic foraminifera, Globigerinoides ruber and Globigerina bulloides, from the tropical North Atlantic Ocean. Oxygen isotope values of T. heimii shells from the Late Holocene fell between $-0.5 \%$ and $-1 \%$. The authors calculated seawater temperatures using the equation of Zonneveld [2004] (Figure 1) and found unrealistically low temperatures. As an alternative, they assumed that calcite precipitation of calcareous dinoflagellates occurred in isotopic equilibrium with ambient water, using the raw equation of Kim and O'Neil [1997]. The results appeared to be more consistent with what was expected for the thermal status of the upper water column of this interval, especially when compared to foraminiferal data.

Yet in the study by Kohn et al. [2011], the $\delta^{18} \mathrm{O}$ of T. heimii were measured $\sim 0.5 \%$ o heavier than G. ruber (var. pink), a symbiotic foraminifera that spends its entire life cycle in the mixed layer [Deuser and Ross, 1989; Farmer et al., 2007; Pearson, 2012]. Reconstructing similar temperatures from T. heimii and G. ruber is still a contentious result, as these organisms calcify in distinct water masses. Instead, the recorded oxygen isotope offset between both taxa that calcify in equilibrium with seawater supports relatively deep habitat for $T$. heimii. At the sites of Kohn et al. [2011], the present-day temperature difference between mixed layer and intermediate photic zone waters is $\sim 3^{\circ} \mathrm{C}$. Applying our calibration to $T$. heimii $\delta^{18} \mathrm{O}$ would reconcile the data. Indeed, this alternative correction of $\delta^{18} \mathrm{O}$ values in $T$. heimii would lead to a decrease of $\sim 2^{\circ} \mathrm{C}$ in isotopic temperature estimates relative to $G$. ruber (var. pink). This figure would make $T$. heimii-derived temperatures compatible with a calcification depth deeper than G. ruber. Overall, this downcore study case of T. heimii $\delta^{18} \mathrm{O}$ confirms the validity of our calibration for the geological record.

4.3.2. A New Proxy for Thermal Gradients Within the Photic Zone

Recent methodological advances, like that used in the present study, now allow microseparation of coccoliths and calcareous dinoflagellate shells in sediments. These sedimentological techniques enable nearmonospecific geochemical measurements on these nannofossils and hence examination of the vital effect in the geological record [e.g., Bolton and Stoll, 2013]. This effort contributes to the ongoing development of new proxies for evaluating accurate temperatures of the uppermost water column. Coccoliths and some surfacedwelling foraminifera species, such as G. ruber, are ideal for deriving the temperature of the mixed layer, corresponding to SSTs. In addition, there is a promising opportunity to decipher parameters other than temperature by undertaking cross-species comparison of $\delta^{18} \mathrm{O}$ of coccolith taxa [Rickaby et al., 2010; Hermoso et al., 2014]. Due to its deeper habitat, the calibration of $T$. heimii geochemistry is of primary importance since it enables characterization of the intermediate part of the photic zone, i.e., the upper part of the thermocline. Hence, measuring paired coccolith and dinoflagellate calcite isotopes might be used to 
constrain the thermal structure of the photic zone. Comparison of isotopic signals in calcite of the coccolithophore Coccolithus pelagicus before its poleward migration [Bown, 1998; Sato et al., 2004] with those of $T$. heimii would be of particular help for reconstructing thermal gradients within the photic zone and for capturing long-term variability in the thermocline depth. The $\delta^{18} \mathrm{O}_{s w}$ variability within the photic zone is small and usually lower than analytical errors of isotope measurements $( \pm 0.1 \%)$; hence, differences in isotopic signals may reflect a temperature signal, after a suitable correction accounting for the vital effect is achieved. 4.3.3. A Temperature Component Driving $\delta^{13} \mathrm{C}$ of $T$. heimii Calcispheres

There is a positive correlation between carbon isotope composition of $T$. heimii and temperature in our batch cultures (Figure 5). In our cultures, $\delta^{13} \mathrm{C}$ of aqueous $\mathrm{CO}_{2}$ was constant around $-10.2 \%$, whereas the $\delta^{13} \mathrm{C}$ of DIC, predominantly consisting of $\mathrm{HCO}_{3}{ }^{-}$, and hence that of inorganic calcite slightly decreases (Figure 5) [Romanek et al., 1992; Lynch-Stieglitz et al., 1995]. Under the safe assumption that $T$. heimii assimilates $\mathrm{CO}_{2}$ [van de Waal et al., 2013], variation of carbon isotope composition in calcite cannot be explained by the decrease in the isotopic composition of the carbon substrate assimilated by the cell and subsequently used for calcification. Increase in $\delta{ }^{13} \mathrm{C}_{\mathrm{c}}$ of $T$. heimii may not correspond to a change in the magnitude of ${ }^{12} \mathrm{C} /{ }^{13} \mathrm{C}$ fractionation. With elevation in temperature and accompanying higher carbon fixation in organic matter [van de Waal et al., 2013], we hypothesize that the DIC pool used for calcification becomes heavier due to more intense Rayleigh fractionation linked to RUbisCO fractionation that favors ${ }^{12} \mathrm{C}$-carbon. Hence, we hypothesize that the linear relationship between temperature and $\delta^{13} C_{c}$ observed in our cultures may also be driven by a modulation of the Rayleigh fractionation of the carbon isotope system with higher ${ }^{12} \mathrm{C}$ partitioning into organic matter at high temperature [van de Waal et al., 2013]. This biogeochemical feature represents a commonality with the carbon isotope system in symbiot-bearing foraminifera [Bemis et al., 2000].

Overall, covariation in $\delta^{18} \mathrm{O} / \delta^{13} \mathrm{C}$ signals in the geological record should not always be regarded as a diagenetic feature [Marshall, 1992], as this work demonstrates that they may convey a pristine biogeochemical signal. Further investigation of the coupling between the two isotopic systems (oxygen and carbon) should be conducted. Notably, a full mechanistic understanding of stable isotope fractionation in calcite-producing dinoflagellates would also require separate analyses of the internal versus external calcite layers. It would be particularly interesting to determine how the inner layer that is precipitated intracellularly (hence presumably with higher coupling between the photosynthetic and calcification carbon pools) compares isotopically with the outer layer that is supposed to be under a lesser degree of biological control.

\section{Conclusions}

This study represents a reconciled culture and core top calibration of the temperature record on $\delta^{18} \mathrm{O}$ of the calcareous dinoflagellate T. heimii. Previous studies have produced conflicting data between culture results and the natural environment. The combination of two methodologies implemented here, very dilute batch cultures and microseparation of extremely enriched (>90\%) T. heimii assemblages from core top sediments, enabled this successful calibration. Differences with previous studies may originate from a drift in the composition of the growth medium and insufficiently purified sedimentary material, respectively.

Our work demonstrates the near-equilibrium composition of T. heimii calcite for oxygen isotopes. In our culture data, however, there seems to be a mismatch with lower $(1 \% 0) \delta^{18} \mathrm{O}$ with respect to equilibrium below $17^{\circ} \mathrm{C}$, which is not seen in core top data. The cause of this discrepancy remains elusive, although reduced DIC assimilation and consecutive reduced growth rates may explain this change of the vital effect with higher $\mathrm{pH}$ values at the site of calcification. As the occurrence of this species at such low temperatures is rare, this discrepancy does not represent a pitfall for our calibration, although this offset should be kept in mind if T. heimii are extracted from temperate regions. Downcore investigation of stable isotopes from T. heimii microfractions represents a promising means to reconstruct the evolution of temperature of the intermediate photic zone. When combined with the shallower dwelling coccolithophores, interspecies $\delta^{18} \mathrm{O}$ may help unraveling the thermal structure of the mixed layer.

The very negative $\delta^{13} \mathrm{C}$ values in calcite found in this study confirm previous culture and geological evidence. This geochemical feature contrasts with observations made in coccolithophores in which a relatively high degree of coupling between calcification and calcification lead to more positive $\delta^{13} \mathrm{C}$. Furthermore, as both carbon and oxygen isotopes seem to be under a common temperature control, this may help understanding and interpreting covariation between $\delta^{13} \mathrm{C}$ and $\delta^{18} \mathrm{O}$ in the geological record. 
Acknowledgments

The authors would like to thank Nathalie Labourdette for her help in running the mass spectrometer. We owe thanks to Eva Moreno (MNHN) and Franck Bassinot (LSCE) for granting access to the sediment repositories of their respective institutes in Paris. We are also grateful to Rusty Lotti (LDEO) for providing some of the Atlantic sediments. Most of the laboratory work presented in this study has been carried out by Y.C. during a doctoral project funded by an "Emergence" grant by UPMC-University Paris 6. MH was supported by the UKNatural Environment Research Council (grant NE/H015523/1). The authors are grateful to Howard Spero, Sebastian Meier and Associate Editor Bärbel Hönisch for their careful reviews and comments that improved the manuscript. We also thank Heiko Pälike for editorial handling. Data supporting Figures 3-6 are available in Tables 1 and 2 and upon request to FM (fabrice.minoletti@upmc.fr).

\section{References}

Barash, M. S., and V. M. Lavrov (1977), On the thickness of the Holocene sediments within the bottom deposits of the Atlantic Ocean, Oceanology, 17(2), 172-176.

Barry, J. P., J. M. Hall-Spencer, and T. Tyrell (2010), In situ perturbation experiments: natural venting sites, spatial/temporal gradients in ocean $\mathrm{pH}$, manipulative in situ $\mathrm{pCO}_{2}$ perturbations, in Guide to Best Practices for Ocean Acidification Research and Data Reporting, edited by U. Riebesell et al., pp. 123-136, Publications Office of the European Union, Luxembourg.

Bemis, B. E., H. J. Spero, J. Bijma, and D. W. Lea (1998), Reevaluation of the oxygen isotopic composition of planktonic foraminifera: Experimental results and revised paleotemperature equations, Paleoceanography, 13(2), 150-160.

Bemis, B. E., H. J. Spero, D. W. Lea, and J. Bijma (2000), Temperature influence on the carbon isotopic composition of Globigerina bulloides and Orbulina Universa (planktonic foraminifera), Mar. Micropaleontol., 38, 213-228.

Bolton, C. T., and H. M. Stoll (2013), Late Miocene threshold response of marine algae to carbon dioxide limitation, Nature, 500(7464), 558-62, doi:10.1038/nature12448.

Bolton, C. T., H. M. Stoll, and A. Mendez-Vicente (2012), Vital effects in coccolith calcite: Cenozoic climate-pCO 2 drove the diversity of carbon acquisition strategies in coccolithophores?, Paleoceanography, 27, PA4204, doi:10.1029/2012PA002339.

Bown, P. R. (1998), Calcareous Nannofossil Biostratigraphy, British Micropalaeontological Soc. Publ. Ser., Chapman and Hall, London.

Candelier, Y., F. Minoletti, I. Probert, and M. Hermoso (2013), Temperature dependence of oxygen isotope fractionation in coccolith calcite: A culture and core top calibration of the genus Calcidiscus, Geochim. Cosmochim. Acta, 100, 264-281.

Chapman, M. R., N. J. Shackleton, and J.-C. Duplessy (2000), Sea surface temperature variability during the last glacial-interglacial cycle: Assessing the magnitude and pattern of climate change in the North Atlantic, Palaeogeogr. Palaeoclimatol. Palaeoecol., 157(1-2), 1-25, doi:10.1016/S0031-0182(99)00168-6.

Cléroux, C., P. de Menocal, J. Arbuszewski, and B. K. Linsley (2013), Reconstructing the upper water column thermal structure in the Atlantic Ocean, Paleoceanography, 28, 503-516, doi:10.1002/palo.20050.

De Boyer Montégut, C. (2004), Mixed layer depth over the global ocean: An examination of profile data and a profile-based climatology, J. Geophys. Res., 109, C12003, doi:10.1029/2004JC002378.

Deuser, W. G., and E. H. Ross (1989), Seasonally abundant planktonic foraminifera of the Sargasso Sea: Succession, deep-water fluxes, isotopic compositions, and paleoceanographic implications, J. Foraminifer. Res., 19, 268-293.

Dudley, W. C., P. L. Blackwelder, L. E. Brand, and J.-C. Duplessy (1986), Stable isotopic composition of coccoliths, Mar. Micropaleontol., 10, 1-8.

Farmer, E. C., A. Kaplan, P. B. de Menocal, and J. Lynch-Stieglitz (2007), Corroborating ecological depth preferences of planktonic foraminifera in the tropical Atlantic with the stable oxygen isotope ratios of core top specimens, Paleoceanography, 22, PA3205, doi:10.1029/ 2006 PA001361.

Fischer, J., F. Schott, and L. Stramma (1996), Currents and transports of the Great Whirl-Socotra Gyre system during the summer monsoon, August 1993, J. Geophys. Res., 101, 3573-3587.

Friedrich, O., and K. J. S. Meier (2003), Maastrichtian calcareous dinoflagellates stable isotopic indication for the cyst formation depth of Campanian / Maastrichtian calcareous dinoflagellates, Micropaleontology, 49(4), 375-380.

Gottschling, M., S. S. Renner, K. J. S. Meier, H. Willems, and H. Keupp (2008), Timing deep divergence events in calcareous dinoflagellates, J. Phycol., 44, 429-438, doi:10.1111/j.1529-8817.2008.00479.x.

Grousset, F. E., L. D. Labeyrie, J. A. Sinko, M. Cremer, G. C. Bond, J. Duprat, E. Cortijo, and S. Huon (1993), Patterns of ice-rafted detritus in the glacial North Atlantic, Paleoceanography, 8(2), 175-192, doi:10.1029/92PA02923.

Gruber, N., C. D. Keeling, R. B. Bacastow, P. R. Guenther, T. J. Lueker, M. Wahlen, H. A. J. Meijer, W. G. Mook, and T. F. Stocker (1999), Spatiotempora patterns of carbon-13 in the global surface oceans and the oceanic Suess effect, Global Biogeochem. Cycles, 13(2), 307-335.

Guillard, R. R. L. (1975), Culture of phytoplankton for feeding marine invertebrates, in Culture of Marine Invertebrate Animals, edited by W. L. Smith and M. H. Chanley, pp. 22-60, Plenum Press, New York.

Gussone, N., K. A. F. Zonneveld, and H. Kuhnert (2010), Minor element and Ca isotope composition of calcareous dinoflagellate cysts of cultured Thoracosphaera heimii, Earth Planet. Sci. Lett., 289(1-2), 180-188, doi:10.1016/j.epsl.2009.11.006.

Hermoso, M. (2014), Coccolith-derived isotopic proxies in palaeoceanography: Where geologists need biologists, Cryptogamie Algol., $35,323-352$.

Hermoso, M., L. Le Callonnec, F. Minoletti, M. Renard, and S. P. Hesselbo (2009), Expression of the Early Toarcian negative carbon-isotope excursion in separated carbonate microfractions (Jurassic, Paris Basin), Earth Planet. Sci. Lett., 277(1-2), 194-203, doi:10.1016/j.epsl.2008.10.013.

Hermoso, M., T. J. Horner, F. Minoletti, and R. E. M. Rickaby (2014), Constraints on the vital effect in coccolithophore and dinoflagellate calcite by oxygen isotopic modification of seawater, Geochim. Cosmochim. Acta, 141, 612-627, doi:10.1016/j.gca.2014.05.002.

Hildebrand-Habel, T., H. Willems, and G. J. M. Versteegh (1999), Variations in calcareous dinoflagellate associations from the Maastrichtian to Middle Eocene of the western South Atlantic Ocean (Sao Paulo Plateau, DSDP Leg 39, Site 356), Rev. Palaeobot. Palynol., 106, 57-87.

Hinga, K. R., M. A. Arthur, M. E. Q. Pilson, and D. Whitaker (1994), Carbon isotope fractionation by marine phytoplankton in culture: The effects of $\mathrm{CO}_{2}$ concentration, $\mathrm{pH}$, temperature, and species, Global Biogeochem. Cycles, 8(1), 91-102.

Hut, G. (1987), Stable Isotope Reference Samples for Geochemical and Hydrological Investigations, Int. At. Energy Agency, Vienna.

Inouye, I., and R. N. Pienaar (1983), Observations on the life cycle and microanatomy of Thoracosphaera heimii (Dinophyceae) with special reference to its systematic position, South African J. Bot., 2(1), 63-75.

Karwath, B., D. Janofske, F. Tietjen, and H. Willems (2000), Temperature effects on growth and cell size in the marine calcareous dinoflagellate Thoracospaera heimii, Mar. Micropaleontol., 39, 43-51.

Keller, M. D., R. C. Selvin, W. Claus, and R. R. L. Guillard (1987), Media for the culture of oceanic ultraphytoplankton, J. Phycol., 23, 633-638.

Kim, S.-T., and J. R. O'Neil (1997), Equilibrium and nonequilibrium oxygen isotope effects in synthetic carbonates, Geochim. Cosmochim. Acta, 61(16), 3461-3475.

Klöcker, R., G. M. Ganssen, S. J. A. Jung, D. Kroon, and H. Rüdiger (2005), Late Quaternary millennial-scale variability in pelagic aragonite preservation off Somalia, Mar. Micropaleontol., 59(3-4), 171-183, doi:10.1016/j.marmicro.2006.02.004.

Koch, C., and J. R. Young (2007), A simple weighing and dilution technique for determining absolute abundances of coccoliths from sediment samples, J. Nannoplankt. Res., 29, 67-69.

Kohn, M., and K. A. F. Zonneveld (2010), Calcification depth and spatial distribution of Thoracosphaera heimii cysts: Implications for palaeoceanographic reconstructions, Deep Sea Res., Part I, 57(12), 1543-1560, doi:10.1016/j.dsr.2010.09.004.

Kohn, M., S. Steinke, K.-H. Baumann, B. Donner, H. Meggers, and K. A. F. Zonneveld (2011), Stable oxygen isotopes from the calcareous-walled dinoflagellate Thoracosphaera heimii as a proxy for changes in mixed layer temperatures off NW Africa during the last $45,000 \mathrm{yr}$, Palaeogeogr. Palaeoclimatol. Palaeoecol., 302(3-4), 311-322, doi:10.1016/j.palaeo.2011.01.019. 
Langer, G., M. Geisen, K.-H. Baumann, J. Kläs, U. Riebesell, S. Thoms, and J. R. Young (2006), Species-specific responses of calcifying algae to changing seawater carbonate chemistry, Geochem., Geophys., Geosyst., 7, Q09006, doi:10.1029/2005GC001227.

LeGrande, A. N., and G. A. Schmidt (2006), Global gridded data set of the oxygen isotopic composition in seawater, Geophys. Res. Lett., 33, L12604, doi:10.1029/2006GL026011.

Levitus, S., and T. P. de Boyer Montégut (1994), World Ocean Atlas 1994 Volume 4: Temperature, U.S. Gov. Print. Off., Washington, D. C.

Locarnini, R. A., J. I. Mishonov, T. P. Antonov, H. E. Boyer, O. K. Garcia, M. Baranova, M. Zweng, and D. R. Johnson (2010), World Ocean Atlas 2009 Volume 1: Temperature, U.S. Gov. Print. Off., Washington, D. C.

Lynch-Stieglitz, J., T. F. Stocker, W. S. Broecker, and R. G. Fairbanks (1995), The influence of air-sea exchange on the isotopic composition of oceanic carbon: Observations and modeling, Global Biogeochem. Cycles, 9, 653-665.

Marshall, J. D. (1992), Climatic and oceanographic isotopic signals from the carbonate rock record and their preservation, Geol. Mag., 129(2), 143-160.

McCrea, J. M. (1950), On the isotopic chemistry of carbonates and a paleotemperature scale, J. Chem. Phys., 18(6), 849-857.

Minoletti, F., S. Gardin, E. Nicot, M. Renard, and S. Spezzaferri (2001), A new experimental protocol for granulometric separation of calcareous nannofossils assemblages: Paleoecological and geochemical applications, Bull. la Soc. Geol. Fr., 172(4), 437-446.

Minoletti, F., M. de Rafelis, M. Renard, and S. Gardin (2004), Remaniement des nannofossiles calcaires maastrichtiens dans les sédiments du Danien basal de Bidart (France): Arguments isotopiques (carbone et oxygène), Rev. Micropaléontol., 47(3), 145-152, doi:10.1016/ j.revmic.2004.07.001.

Minoletti, F., M. de Rafelis, M. Renard, S. Gardin, and J. Young (2005), Changes in the pelagic fine fraction carbonate sedimentation during the Cretaceous-Paleocene transition: Contribution of the separation technique to the study of Bidart section, Palaeogeogr. Palaeoclimatol. Palaeoecol., 216(1-2), 119-137.

Minoletti, F., M. Hermoso, and V. Gressier (2009), Separation of sedimentary micron-sized particles for palaeoceanography and calcareous nannoplankton biogeochemistry, Nat. Protoc., 4(1), 14-24, doi:10.1038/nprot.2008.200.

Mix, A. C., and W. F. Ruddiman (1985), Structure and timing of the last deglaciation: Oxygen- isotope evidence, Quat. Sci. Rev., 4, 59-108.

Mook, W. G., J. C. Bommerson, and W. H. Staverman (1974), Carbon isotope fractionation between dissolved bicarbonate and gaseous carbon dioxide, Earth Planet. Sci. Lett., 22, 169-176.

Pearson, P. N. (2012), Oxygen isotopes in foraminifera: Overview and historical review, Paleontol. Soc. Pap., 18, 1-38.

Peeters, F. J. C., G. A. Brummer, and G. Ganssen (2002), The effect of upwelling on the distribution and stable isotope composition of Globigerina bulloides and Globigerinoides ruber ( planktic foraminifera ) in modern surface waters of the NW Arabian Sea, Global Planet. Change, 34, 269-291.

Rickaby, R. E. M., J. Henderiks, and J. N. Young (2010), Perturbing phytoplankton: Response and isotopic fractionation with changing carbonate chemistry in two coccolithophore species, Clim. Past, 6(6), 771-785, doi:10.5194/cp-6-771-2010.

Romanek, C. S., E. L. Grossman, and J. W. Morse (1992), Carbon isotopic fractionation in synthetic aragonite and calcite: Effects of temperature and precipitation rate, Geochim. Cosmochim. Acta, 56(1), 419-430, doi:10.1016/0016-7037(92)90142-6.

Rousselle, G., C. Beltran, M.-A. Sicre, I. Raffi, and M. De Rafélis (2013), Changes in sea-surface conditions in the Equatorial Pacific during the middle Miocene-Pliocene as inferred from coccolith geochemistry, Earth Planet. Sci. Lett., 361, 412-421, doi:10.1016/j.epsl.2012.11.003.

Sato, T., S. Yuguchi, T. Takayama, and K. Kameo (2004), Drastic change in the geographical distribution of the cold-water nannofossil Coccolithus pelagicus (Wallich) Schiller at 2.74 Ma in the late Pliocene, with special reference to glaciation in the Arctic Ocean, Mar. Micropaleontol., 52, 181-193.

Schott, F. A., S.-P. Xie, and J. P. McCreary (2009), Indian Ocean circulation and climate variability, Rev. Geophys., 47, RG1002, doi:10.1029/ 2007RG000245.

Spero, H. J., J. Bijma, D. W. Lea, and B. E. Bemis (1997), Effect of seawater carbonate concentration on foraminiferal carbon and oxygen isotopes, Nature, 390, 497-500, doi:10.1038/nature37333.

Spero, H. J., K. M. Mielke, E. M. Kalve, D. W. Lea, and D. K. Pak (2003), Multispecies approach to reconstructing eastern equatorial Pacific thermocline hydrography during the past 360 kyr, Paleoceanography, 18(1), 1022, doi:10.1029/2002PA000814.

Stoll, H. M. (2005), Limited range of interspecific vital effects in coccolith stable isotopic records during the Paleocene-Eocene thermal maximum, Paleoceanography, 20, PA1007, doi:10.1029/2004PA001046.

Stoll, H. M., and P. Ziveri (2002), Separation of monospecific and restricted coccolith assemblages from sediments using differential settling velocity, Mar. Micropaleontol., 46, 209-221.

Stoll, H. M., and P. Ziveri (2004), Coccolithophore-based geochemical proxies, in Coccolithophores: From Molecular Processes to Global Impact, edited by H. R. Thierstein and J. Young, pp. 529-562, Springer, Berlin.

Tangen, K., L. E. Brand, P. L. Blackwelder, and R. R. L. Guillard (1982), Thoracosphaera heimii (Lohmann) Kamptner is a dinophyte: Observations on its morphology and life cycle, Mar. Micropaleontol., 7(3), 193-212.

Thomas, W. H., and C. H. Gibson (1990), Effects of small-scale turbulence on microalgae, J. Appl. Phycol., 2(1), 71-77, doi:10.1007/BF02179771.

Uchikawa, J., and R. E. Zeebe (2012), The effect of carbonic anhydrase on the kinetics and equilibrium of the oxygen isotope exchange in the $\mathrm{CO}_{2}-\mathrm{H}_{2} \mathrm{O}$ system: Implications for $\delta^{18} \mathrm{O}$ vital effects in biogenic carbonates, Geochim. Cosmochim. Acta, 95, 15-34, doi:10.1016/ j.gca.2012.07.022.

Van de Waal, D. B., U. John, P. Ziveri, G.-J. Reichart, M. Hoins, A. Sluijs, and B. Rost (2013), Ocean acidification reduces growth and calcification in a marine dinoflagellate, edited by H. I. Browman, PLoS One, 8(6), e65987, doi:10.1371/journal.pone.0065987.

Vink, A. (2004), Calcareous dinoflagellate cysts in South and equatorial Atlantic surface sediments: Diversity, distribution, ecology and potential for palaeoenvironmental reconstruction, Mar. Micropaleontol., 50(1-2), 43-88, doi:10.1016/50377-8398(03)00067-7.

Vink, A., K. A. F. Zonneveld, and H. Willems (2000), Distributions of calcareous dinoflagellate cysts in surface sediments of the western equatorial Atlantic Ocean, and their potential use in palaeoceanography, Mar. Micropaleontol., 38, 149-180, doi:10.1016/S0377-8398(99)00038-9.

Vogelsang, E., M. Sarnthein, and U. Pflaumann, (2001), $\delta^{18}$ O Stratigraphy, chronology, and sea surface temperatures of Atlantic sediment records (GLAMAP-2000 Kiel), Berichte-Reports, Institut für Geowissenschaften, Universität Kiel, 13, doi:10.2312/reports-ifg.2001.13

Watkins, J. M., J. D. Hunt, F. J. Ryerson, and D. J. DePaolo (2014), The influence of temperature, $\mathrm{pH}$, and growth rate on the $\delta^{18} \mathrm{O}$ composition of inorganically precipitated calcite, Earth Planet. Sci. Lett., 404, 332-343, doi:10.1016/j.epsl.2014.07.036.

Wendler, I., K. A. F. Zonneveld, and H. Willems (2002a), Oxygen availability effects on early diagenetic calcite dissolution in the Arabian Sea as inferred from calcareous dinoflagellate cysts, Global Planet. Change, 34, 219-239.

Wendler, l., K. A. Zonneveld, and H. Willems (2002b), Production of calcareous dinoflagellate cysts in response to monsoon forcing off Somalia: A sediment trap study, Mar. Micropaleontol., 46(1-2), 1-11, doi:10.1016/S0377-8398(02)00049-X.

Young, J. R., and P. Ziveri (2000), Calculation of coccolith volume and it use in calibration of carbonate flux estimates, Deep Sea Res. Part II, 47(9-11), 1679-1700, doi:10.1016/S0967-0645(00)00003-5. 
Zeebe, R. E. (1999), An explanation of the effect of seawater carbonate concentration on foraminiferal oxygen isotopes, Geochim. Cosmochim. Acta, 63(13-14), 2001-2007.

Zeebe, R. E. (2001), Seawater pH and isotopic paleotemperatures of Cretaceous oceans, Palaeogeogr. Palaeoclimatol. Palaeoecol., 170, 49-57. Zeebe, R. E., and D. A. Wolf-Gladrow (2001), $\mathrm{CO}_{2}$ in Seawater: Equilibrium, Kinetics, Isotopes, Elsevier Oceanogr. Ser., Elsevier, Amsterdam.

Zeebe, R. E., D. A. Wolf-Gladrow, and H. Jansen (1999), On the time required to establish chemical and isotopic equilibrium in the carbon dioxide system in seawater, Mar. Chem., 65, 49-57.

Ziveri, P., H. M. Stoll, I. Probert, C. M. Klaas, M. Geisen, and G. Ganssen (2003), Stable isotope " vital effects " in coccolith calcite, Earth Planet. Sci. Lett., 210, 137-149, doi:10.1016/S0012-821X(03)00101-8

Ziveri, P., S. Thoms, I. Probert, M. Geisen, and G. Langer (2012), A universal carbonate ion effect on stable oxygen isotope ratios in unicellular planktonic calcifying organisms, Biogeosciences, 9(3), 1025-1032, doi:10.5194/bg-9-1025-2012.

Zonneveld, K. A. F. (2004), Potential use of stable oxygen isotope composition of Thoracosphaera heimii (Dinophyceae) for upper watercolumn (thermocline) temperature reconstruction, Mar. Micropaleontol., 50(3-4), 307-317, doi:10.1016/S0377-8398(03)00097-5.

Zonneveld, K. A. F., A. Brune, and H. Willems (2000), Spatial distribution of calcareous dinoflagellate cysts in surface sediments of the Atlantic Ocean between 13 degrees N and 36 degrees S, Rev. Palaeobot. Palynol., 111(3-4), 197-223.

Zonneveld, K. A. F., A. Mackensen, and K.-H. Baumann (2007), Stable oxygen isotopes of Thoracosphaera heimii (Dinophyceae) in relationship to temperature; a culture experiment, Mar. Micropaleontol., 64(1-2), 80-90, doi:10.1016/j.marmicro.2007.03.002. 